\title{
中央に変位拘束部材を有する弦の自由振動 （弦と変位拘束部材との間にギャップがある場合）
}

\section{Free vibration analysis of a string with vibration suppressor located at center of the string (When there is a gap between string and vibration suppressor)}

\author{
Hiroyuki KIMURA *1 \\ ${ }^{* 1}$ Graduate School of Science and Engineering for Research (Engineering), Toyama University \\ 3190 Gofuku, Toyama-shi, Toyama 930-8555, Japan
}

Received 25 September 2015

\begin{abstract}
When an elevator rope for a high-rise building is forcibly excited by the displacements of the building induced by wind forces and/or by long-period ground motion, rope displacement becomes large even if the ground acceleration and the buildings acceleration are small. In previous paper, when elevator cage is stationary, a new practical method for reducing the rope vibration by using vibration suppressors is proposed for relaxing the restricted elevator operation. The advantage of using the vibration suppressors for reducing the rope lateral vibration is demonstrated through numerical calculation. Further, when arbitrary position of the rope is pulled, exact solution to the free vibration of the rope with vibration suppressor, which located at the center of the rope and the gap between rope and vibration suppressor is 0 , has been presented. However, in the case where the position of vibration suppressor is center of the rope and the gap between rope and vibration suppressor is not 0 , no exact solution to the free vibration has yet been obtained. In this paper, an exact solution to the free vibration of this case is presented. In the analysis, the rope is modeled with string. Finite difference analyses of the rope vibration with vibration suppressor are also performed to verify the validity of this exact solution. The calculated results of the finite difference analyses are in fairly good agreement with those of the exact solution.
\end{abstract}

Key words : Elevator, Vibration suppressor, Free vibration, String, Exact solution, Rope sway

\section{1. 緒言}

超高層ビルに設置されるエレベータにおいては，強風時や地震時には建物とロープとの共振によりロープが大 きく摇れ, 昇降路内機器への衝突や絡まりが問題となることがある.このため, エレベータの運転効率向上や安 全性確保の観点からロープ摇れの抑制が望まれている.このロープ摇れの抑制に関しては，従来からいくつかの 研究が行われている. 走行中のロープ長さの変化を考慮してロープ摇れを制御する方法(大槻他，2002)，ロープ 摇れを振れ止め枠等で拘束する方法(木村, 中川, 2005), 建物の摇れに共振しないようにかご位置を移動させる方 法(渡辺他, 2007), 永久磁石の吸引力を利用してロープ摇れを非接触で制御する方法(勝野他, 2007), コンペンシ 一ブにダンパーを取り付け上下方向の振動に減衰を加えることでロープ摇れを抑える方法(中川，新井，2012)等 が提案されている. また最近では, 動吸振器を用いる方法 (木村, 番匠, 2015) や釣合いおもりの上下動を利用す る方法 (廣瀬他, 2015) 等, ロープ張力の変動を利用してロープ摇れを抑制する方法についての研究も行われてい る.

しかし，実際のエレベータに適用されているのは，振れ止め枠（変位拘束部材）をかご側と釣合いおもり側の ロープの間に設置することで，ロープ変位を物理的に制限しかつ， ロープの固有振動数を変化させ共振を回避す る方法(中川他, 2005)のみである.

\footnotetext{
No.15-00535 [DOI:10.1299/transjsme.15-00535], J-STAGE Advance Publication date : 5 January, 2016

${ }^{* 1}$ 正員, 富山大学 大学院理工学研究部 (工学) (广930-8555 富山県富山市五福 3190)

E-mail of corresponding author: hkimura@eng.u-toyama.ac.jp
} 
著者はこれまでに，変位拘束部材を有するロープの振動について，ロープを弦でモデル化して解析を行ってき た．ロープ片側に変位拘束部材が 1 個または複数個設置された場合のロープの強制振動について, 差分法による 数值解析を行い, 変位拘束部材がロープ摇れの抑制に有効であることやその抑制効果は変位拘束部材の設置個数, 設置範囲，ロープとのギャップに大きく依存することを示している(木村，中川, 2005). 強制振動時のロープ摇れ について理論解が得られれば，その都度数值解析を行うことなく枠の最適な設置位置や個数を決定できるように なる. しかし，このような変位拘束部材を有寸る弦の振動は，その幾何学的な非線形性がゆえに限られた条件で しか解かれていない.

そこで，まず自由振動時のロープ摇れについての理論解を得ることを目的として，図 1(a), 図 1(b)に示すよう にロープ片側に等間隔に変位拘束部材が配置された場合を対象とし，ロープ中央または全長の $1 / N$ を引張った場 合の理論解を求め, その固有振動数や変位拘束部材からのロープのはみ出し量も求めている(木村, 2013,2014). ま た, 図 1(c)に示すようにギャップがある場合を含めて変位拘束部材が 1 個, ロープ全長の $1 / N$ の位置に配置され, $1 / N$ の位置を引張った場合の自由振動について理論解を求め, その固有振動数を求めている(木村, 2014). さらに, 図 1(d)に示すようにギャップが 0 で変位拘束部材が 1 個ロープ中央に配置され，任意の位置を引張った場合の自 由振動について理論解を求め, その固有振動数や変位拘束部材からのロープのはみ出し量を求めている(木村, 2015).

しかし，ギャップがある場合については検討されていない，そこで本研究では，ロープ中央に変位拘束部材が 1 個あり, さらにロープとの間にギャップがあり, 任意の位置を引張った場合について理論解を求める. また, 差分法による数值解析も行い結果を比較する.
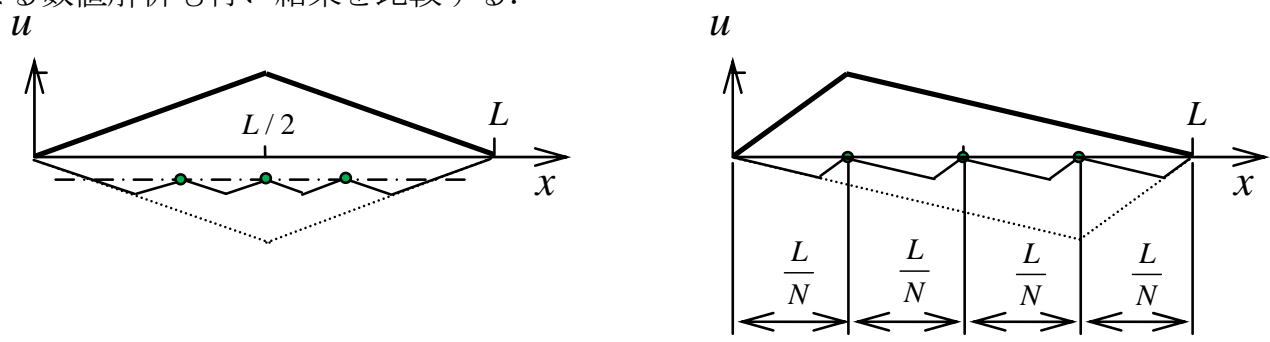

(a) $L / 2, N=4, N s=N-1$

$u$

$u$

(b) $L / N, N=4, N \mathrm{~s}=N-1$
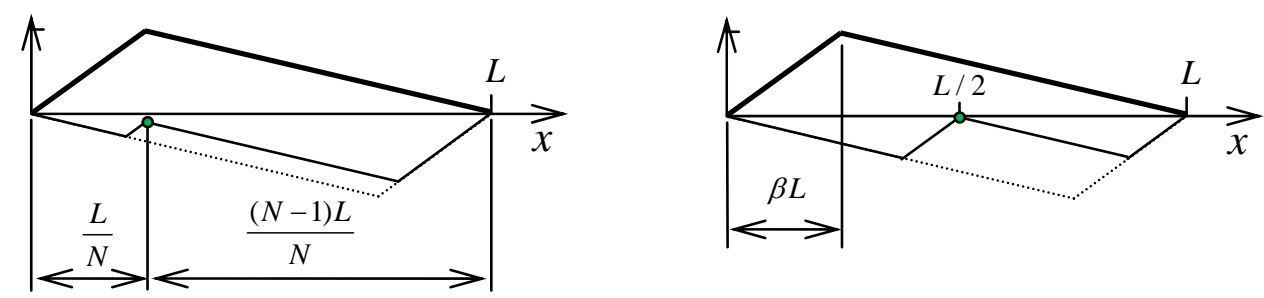

(c) $L / N, L / N, N s=1$

(d) $\beta L, L / 2, N \mathrm{~s}=1$

Fig. 1 Initial rope displacement and vibration suppressors

(pulled position, divided number or position of vibration suppressor, number of vibration suppressors)

\section{2. 解 析 方 法}

\section{$2 \cdot 1$ 片側中央に振れ止め枠（変位拘束部材）が 1 個ある場合の理論解析}

\section{$2 \cdot 1 \cdot 1$ 全長の $1 / N$ の位置を引張った場合}

ロープを弦でモデル化し, 図 2 に示すように全長の $1 / N$ の位置を引張り, 初期変位を与えた後に, 解放した場 合の自由振動について考える，この初期変位は，次式で表される．ただし， $N$ は 3 以上の整数で，ロープ張力は 一様，初期速度は 0 とし，振れ止枠（変位拘束部材）はロープ（弦）中央に 1 個あるとする. なお， $N$ が 2 の 場合については, すでに理論解（木村, 2013）が得られているため対象外とする. また, ロープと枠とのギャッ プは $\delta_{0}$ とする.

$$
u(x, 0)= \begin{cases}N \times \frac{x}{L} u_{\max } & (0 \leq x \leq L / N) \\ \frac{N}{N-1} \times\left(1-\frac{x}{L}\right) u_{\max } & (L / N \leq x \leq L)\end{cases}
$$


ここで, $L$ : ロープ長さ, $u_{\max }$ : ロープ引張量である.

ロープ解放後の波の伝播の様子を図 3 に示寸. 図 3 には $N=3, \alpha \equiv \delta_{0} / u_{\max }=0.25$ の例を示している. 図中の 直線は，例えばロープを解放した際に発生する波が，A 点からスタートして両端や枠の位置で反射を繰り返しま た元の引張り位置まで戻るまでの波の位置（座標 $x$ と時間 $t$ ）を表している．また，ロープが中央に設置された 枠に衝突する際（B 点，C 点，D点）にも波が発生する．なお，ロープ中央（枠の設置位置）を波が通過する際 に, ロープが枠に接触している場合はそこで反射し, ロープと枠とが離れている場合には波はそのまま通過する.

振れ止め枠にロープが衝突するまで $\left(t<T_{A}\right)$ は枠が無い場合と同じである.A 点から出た波が左右に伝播し 両端で反射する一方， B 点 $\left(t=T_{A}\right)$ でロープが枠に接触し新たに波が発生する. 図中の B-B'間， C-C’間および D-D’間でロープから枠に荷重が作用する．また，同じ荷重が枠からロープに作用する．この場合，振れ止め枠に は図 4 に示すように 3 回荷重が作用寸る. なお， B’-C間，C’-D間でもロープ中央に波が伝播しているが，ロー プと枠とが離れているか枠の片側しかロープがはみ出していないため，波は通過するのみで枠には新たな荷重は 作用しない。

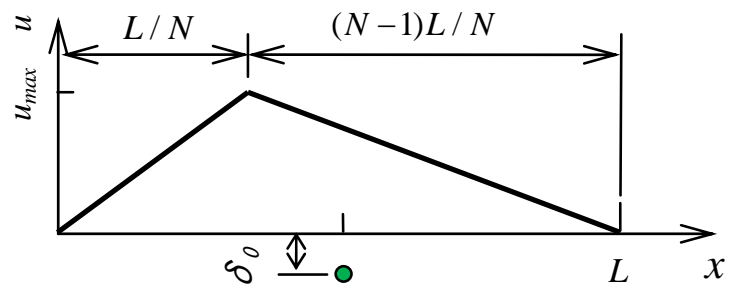

Fig. 2 Initial rope displacement

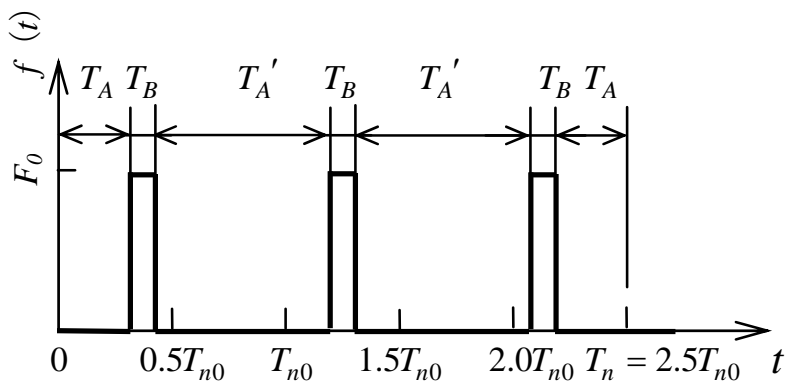

Fig. 4 Time history of reaction force $\left(N=3, \quad \alpha \equiv \delta_{0} / u_{\max }=0.25\right)$

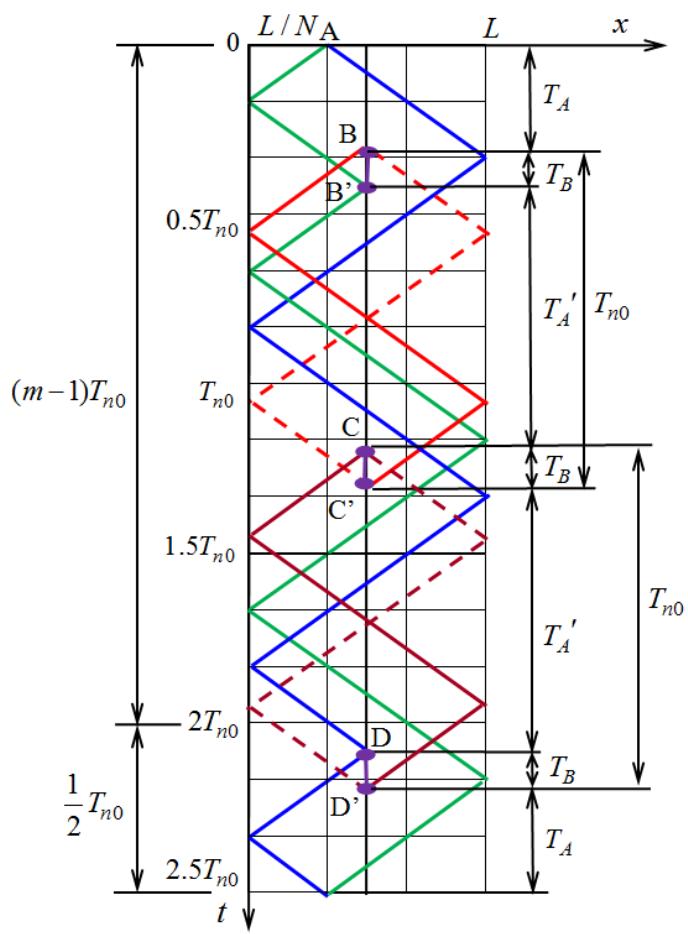

Fig. 3 Propagation waves of rope ( $N=3, \quad \alpha=0.25$ )

枠が無い場合の固有周期を $T_{n 0}$ とすると, 枠と接触していない時間 $T_{A}, T_{A}{ }^{\prime}$, 接触している時間 $T_{B}$ および周期 $T_{n}$ は次式で表される.

$$
\begin{aligned}
& T_{A}=\left(\frac{1}{4}+\frac{N-1}{N^{2}} \alpha\right) T_{n 0} \\
& T_{B}=\left(1-\frac{2(N-1)}{N} \alpha\right) \frac{1}{2 N} T_{n 0} \\
& T_{A}{ }^{\prime}=T_{n 0}-2 T_{B}=\left\{\frac{N-1}{N}+\frac{2(N-1)}{N^{2}} \alpha\right\} T_{n 0}
\end{aligned}
$$

ロープの枠への衝突回数を $m$ とすると，図 3 右側に示すように周期は次式で表される. 


$$
T_{n}=2 T_{A}+(m-1) T_{n 0}-(m-2) T_{B}=\left\{\frac{2 m-1}{2}+\frac{m(N-1)}{N^{2}} \alpha-\frac{m-2}{2 N}\right\} T_{n 0}
$$

一方，図 3 左側に示寸ように，周期は次式のように表すこともできる.

$$
T_{n}=(m-1) T_{n 0}+\frac{1}{2} T_{n 0}=\left(m-\frac{1}{2}\right) T_{n 0}
$$

式(5)および式(6)より，次式が得られる.

$$
\alpha=\frac{m-2}{m} \frac{N}{2(N-1)}
$$

すなわち，式(7)の関係を満足するときに，式(6)に示す固有周期を持つことが分かる.

したがって, 枠が無い場合の固有振動数を $f_{n 0}$ とすると枠がある場合の固有振動数 $f_{n}$ は次式で表される.

$$
f_{n}=\frac{2}{2 m-1} f_{n 0}
$$

このとき，枠に作用する荷重の大きさは，ロープ張力との力の釣合いから初期変位 $u_{\max }$, 張力 $T_{0}$ を用い, $F_{0}=\left(N^{2} /(N-1)\right) u_{\max } T_{0} / L \quad$ と表される. なお, 衝突によるエネルギ損失はないものとする. この荷重波形の区 間 $t=0$ から $T_{n}$ に着目し，この波形が偶関数であることを考慮し，荷重 $f(t)$ をフーリエ級数展開することで, 次式が得られる。

$$
\begin{aligned}
f(t)=F_{0}\left[\frac{2}{(2 m-1) N}+\frac{2}{\pi} \sum_{k=1}^{\infty} \frac{1}{k}\left\{\sum _ { j = 1 } ^ { m } \left(\sin \left\{j-\frac{3}{4}+\left(1-\frac{2(j-1)}{m}\right) \frac{1}{2 N}\right\} \frac{2 k \pi}{2 m-1}\right.\right.\right. \\
\left.\left.\left.\quad-\sin \left\{j-\frac{3}{4}+\left(1-\frac{2 j}{m}\right) \frac{1}{2 N}\right\} \frac{2 k \pi}{2 m-1}\right)\right\} \cos \frac{2 k \pi t}{(2 m-1) T_{n 0}}\right] \\
=F_{0}\left[\frac{2}{(2 m-1) N}+\frac{4}{\pi} \sum_{k=1}^{\infty} \frac{1}{k}\left\{\sum_{j=1}^{m}\left(\cos \left\{j-\frac{3}{4}+\left(1-\frac{2 j-1}{m}\right) \frac{1}{2 N}\right\} \frac{2 k \pi}{2 m-1} \cdot \sin \left\{\frac{k \pi}{m(2 m-1) N}\right\}\right)\right\} \cos \frac{2 k \pi t}{(2 m-1) T_{n 0}}\right]
\end{aligned}
$$

したがって，この自由振動の問題は，ロープ中央に次式で表される集中荷重が作用する強制振動の問題に置き 換えることができる.

$$
\begin{aligned}
f(x, t)=F_{0} \delta\left(x-\frac{L}{2}\right)\left[\frac{2}{(2 m-1) N}+\frac{4}{\pi} \sum_{k=1}^{\infty}\right. & \frac{1}{k}\left\{\sum _ { j = 1 } ^ { m } \left(\cos \left\{j-\frac{3}{4}+\left(1-\frac{2 j-1}{m}\right) \frac{1}{2 N}\right\} \frac{2 k \pi}{2 m-1}\right.\right. \\
& \left.\left.\left.\times \sin \left\{\frac{k \pi}{m(2 m-1) N}\right\}\right)\right\} \cos \frac{2 k \pi t}{(2 m-1) T_{n 0}}\right]
\end{aligned}
$$

ここで, $\delta(x-L / 2)$ はディラックのデルタ関数であり, 式(10)のフーリエ級数の定数項 $2 F_{0} /((2 m-1) N)$ は, ロープ中央に静荷重 $2 F_{0} /((2 m-1) N)$ が作用寸る場合に対応している. その解は次式で表される.

$$
u_{1}(x, t)= \begin{cases}\frac{N}{(2 m-1)(N-1)} \times \frac{x}{L} u_{\max } & (0 \leq x \leq L / 2) \\ \frac{N}{(2 m-1)(N-1)} \times\left(1-\frac{x}{L}\right) u_{\max } & (L / 2 \leq x \leq L)\end{cases}
$$

残りの第 2 項以降に対応寸る解は, 弦中央を正弦波加振された場合の解(安田, 2000) を応用寸ることで次式のよ うに得られる. なおここで, $m=2$ とすれば, $\alpha=0\left(\delta_{0}=0\right)$ となり, 前報の結果(木村, 2015) と一致する. 


$$
\begin{aligned}
u_{2}(x, t) & =\frac{8 N^{2} u_{\max }}{(N-1) \pi^{3}} \sum_{k=1}^{\infty} \sum_{i=1}^{\infty}\left\{\frac{(-1)^{i-1}}{(2 i-1)^{2}-\left(\frac{k}{2 m-1}\right)^{2}} \cdot \frac{1}{k} \cdot \sin \frac{(2 i-1) \pi x}{L}\right\} \\
& \times\left[\sum_{j=1}^{m}\left(\cos \left\{j-\frac{3}{4}+\left(1-\frac{2 j-1}{m}\right) \frac{1}{2 N}\right\} \frac{2 k \pi}{2 m-1} \cdot \sin \left\{\frac{k \pi}{m(2 m-1) N}\right\}\right)\right] \cos \frac{2 k \pi t}{(2 m-1) T_{n 0}}
\end{aligned}
$$

また，前報(木村, 2015) と同じように，式(11) と式(12)を足し合わせても式(1)や図 2 に示す初期変位とは一致 しない，これは，式(10)に示寸荷重がロープ中央に作用しているため，この荷重からは図 5(a)に示寸ように左右 対称の初期変位しが得られないためである. そこで, $u_{1}(x, 0)+u_{2}(x, 0)$ と式 $(1)$ に示寸初期変位との差を $u_{3}(x, 0)$ と置き (図 5(b)), これに対する自由振動解を加える必要がある.

この $u_{1}(x, 0)+u_{2}(x, 0)$ は， ロープ中央を力加振した場合の解であるため左右対称の変位分布となり，1/Nの位 置を引張った場合の初期変位 (式 $(1))$ と $(N-1) / N$ の位置を引張った場合の初期変位との平均值となる. これを 次式に示す.

$$
u_{1}(x, 0)+u_{2}(x, 0)= \begin{cases}\frac{N^{2}}{2(N-1)} \times \frac{x}{L} u_{\max } & \left(0 \leq x \leq \frac{L}{N}\right) \\ \frac{N}{2(N-1)} \times u_{\max } & \left(\frac{L}{N} \leq x \leq \frac{N-1}{N} L\right) \\ \frac{N^{2}}{2(N-1)} \times\left(1-\frac{x}{L}\right) u_{\max } & \left(\frac{N-1}{N} L \leq x \leq L\right)\end{cases}
$$

したがって, $u_{3}(x, 0)$ は次式で表される.

$$
u_{3}(x, 0)=u(x, 0)-u_{1}(x, 0)-u_{2}(x, 0)=\left\{\begin{array}{lc}
\frac{N(N-2)}{2(N-1)} \times \frac{x}{L} u_{\max } & \left(0 \leq x \leq \frac{L}{N}\right) \\
\frac{N}{(N-1)}\left(\frac{1}{2}-\frac{x}{L}\right) \times u_{\max } & \left(\frac{L}{N} \leq x \leq \frac{N-1}{N} L\right) \\
\frac{N(2-N)}{2(N-1)} \times\left(1-\frac{x}{L}\right) u_{\max } & \left(\frac{N-1}{N} L \leq x \leq L\right)
\end{array}\right.
$$

この初期変位 $u_{3}(x, 0)$ に対する自由振動解は，初期速度を 0 とすることで次式のように求められる.

$$
u_{3}(x, t)=\frac{N^{2} u_{\max }}{2(N-1) \pi^{2}} \sum_{k=1}^{\infty}\left[\frac{1}{k^{2}} \cdot \sin \frac{2 k \pi}{N} \cdot \sin \frac{2 k \pi x}{L} \cdot \cos \frac{4 k \pi t}{T_{n 0}}\right]
$$

したがって，ロープ中央に振れ止め枠があり，全長の $1 / N$ の位置を引張った場合の自由振動の解は，次式のよ うにこれらを足し合わせることで得られる。

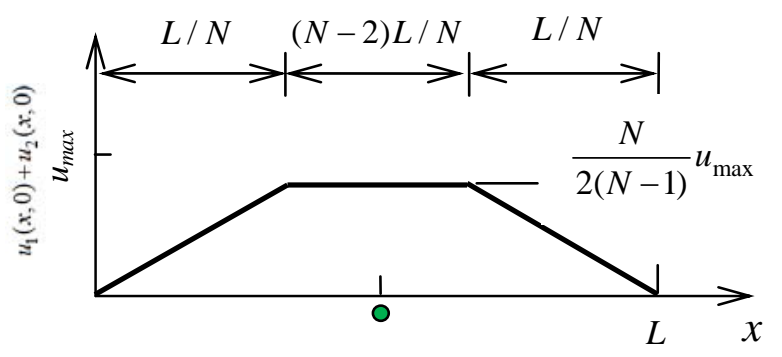

(a) $u_{1}(x, 0)+u_{2}(x, 0)$

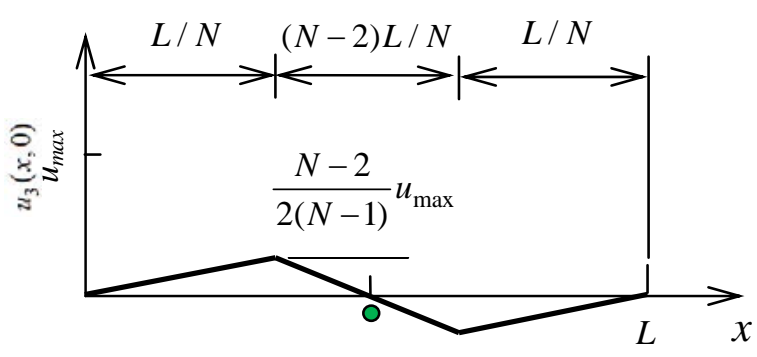

(b) $u_{3}(x, 0)$

Fig. 5 Initial rope displacement $\left(u_{1}(x, 0)+u_{2}(x, 0), u_{3}(x, 0)\right)$ 


$$
u(x, t)=u_{1}(x, t)+u_{2}(x, t)+u_{3}(x, t)
$$

なお，以上の結果から明らかなように， $u(x, t)=u_{1}(x, t)+u_{2}(x, t)$ とすれば，図 $5(\mathrm{a})$ に示すように対称に 2 点を 引張った場合（初期変位分布は台形）の自由振動解となる.

\section{$2 \cdot 1 \cdot 2$ 任意の位置を引張った場合}

図 6 に示すように任意の位置 $(\beta L: 0<\beta<0.5)$ を引張った場合の固有振動数，荷重および自由振動の解を求 める. 図 3 に示す波の伝播から明らかなように，引張り位置が $L / N$ である必要はなく，任意の位置（図 3 にお ける A 点の位置が左右に移動）でも波の伝播の様子は同様である.

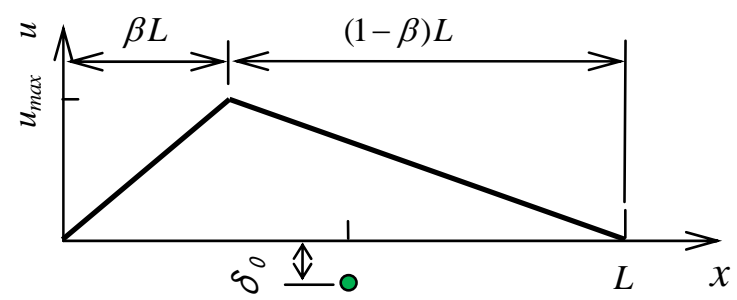

Fig. 6 Initial rope displacement

したがって，前節と同様に周期解を持つための条件や解が以下のように得られる.

$$
\begin{aligned}
& \alpha=\frac{m-2}{m} \frac{1}{2(1-\beta)} \\
& T_{A}=\left(\frac{1}{4}+\frac{(m-2) \beta}{2 m}\right) T_{n 0} \\
& T_{B}=\frac{\beta}{m} T_{n 0} \\
& T_{A}{ }^{\prime}=(1-\beta)(1+2 \beta \alpha) T_{n 0} \\
& T_{n}=\left(m-\frac{1}{2}\right) T_{n 0} \\
& f_{n}=\frac{2}{2 m-1} f_{n 0} \\
& u_{1}(x, t)=\left\{\frac{1}{(2 m-1)(1-\beta)} \times \frac{x}{L} u_{\max }\right. \\
& f(x, t)=F_{0} \delta\left(x-\frac{L}{2}\right)\left[\frac{1}{2 m-1}+\frac{4}{\pi} \sum_{k=1}^{\infty} \frac{1}{k}\left\{\sum _ { j = 1 } ^ { m } \left(\cos \left\{j-\frac{3}{4}+\left(1-\frac{2 j-1}{m}\right) \frac{\beta}{2}\right\} \frac{2 k \pi}{2 m-1}\right.\right.\right.
\end{aligned}
$$




$$
\begin{aligned}
u_{2}(x, t) & =\frac{8 u_{\max }}{\beta(1-\beta) \pi^{3}} \sum_{k=1}^{\infty} \sum_{i=1}^{\infty}\left\{\frac{(-1)^{i-1}}{(2 i-1)^{2}-\left(\frac{k}{2 m-1}\right)^{2}} \cdot \frac{1}{k} \cdot \sin \frac{(2 i-1) \pi x}{L}\right\} \\
& \times\left[\sum_{j=1}^{m}\left(\cos \left\{j-\frac{3}{4}+\left(1-\frac{2 j-1}{m}\right) \frac{\beta}{2}\right\} \frac{2 k \pi}{2 m-1} \cdot \sin \left\{\frac{\beta k \pi}{m(2 m-1)}\right\}\right)\right] \cos \frac{2 k \pi t}{(2 m-1) T_{n 0}} \\
u_{3}(x, t) & =\frac{u_{\max }}{2 \beta(1-\beta) \pi^{2}} \sum_{k=1}^{\infty}\left[\frac{1}{k^{2}} \cdot \sin 2 k \beta \pi \cdot \sin \frac{2 k \pi x}{L} \cdot \cos \frac{4 k \pi t}{T_{n 0}}\right]
\end{aligned}
$$

したがって，ロープ中央に振れ止め枠があり， $\beta L$ の位置を引張った場合の自由振動の解は，式(24)〜式(26) を足し合わせることで得られる.

$$
u(x, t)=u_{1}(x, t)+u_{2}(x, t)+u_{3}(x, t)
$$

\section{$2 \cdot 2$ 差分法による解析}

ロープを弦でモデル化する，長さ一定の弦の運動方程式は，一端からの距離を $s$, 変位を $u$ とすると次式で表 される.

$$
\rho A \frac{\partial^{2} u}{\partial t^{2}}-\frac{\partial}{\partial s}\left(T \frac{\partial u}{\partial s}\right)+C \frac{\partial u}{\partial t}=0
$$

ここで, $\rho A$ はロープの単位長さ当りの質量, $T$ はロープ張力, $C$ はロープの単位長さ当りの減衰係数である.

本報ではロープの片側に振れ止め枠がある場合を解析対象とし， ロープ張力 $T=T_{0}$ 一定とする. 式(29)の運 動方程式を次式の差分近似(木村他, 2006)を行うことにより数值解析を行う.

$$
\left(1+\frac{C}{\rho A} \frac{\Delta t}{2}\right) u_{i, j+1}=2\left(1-\frac{\Delta t^{2}}{\Delta s^{2}} \frac{T_{0}}{\rho A}\right) u_{i, j}+\frac{\Delta t^{2}}{\Delta s^{2}} \frac{T_{0}}{\rho A} u_{i+1, j}+\frac{\Delta t^{2}}{\Delta s^{2}} \frac{T_{0}}{\rho A} u_{i-1, j}+\left(-1+\frac{C}{\rho A} \frac{\Delta t}{2}\right) u_{i, j-1}
$$

ここで， $\Delta t$ は時間刻み， $\Delta s$ は分割したロープ要素の長さ，添字 $i j$ はそれぞれ空間座標，時間座標における 格子点の番号を表している. 式(29)を用いロープに初期変位を入力することで, その後の自由振動時のロープ変 位を計算する．また時々刻々，ロープ変位と枠位置とを比較することで接触判定を行い，枠設置位置ではロープ 変位は枠の位置を超えないとして数值解析を行う.

\section{3. 結果および考察}

\section{$3 \cdot 1$ 振れ止め枠（変位拘束部材）に作用する荷重}

振れ止め枠に作用寸る荷重を式(9)により計算した結果の一例を図 7 に示寸. これらの図から, 荷重が作用し始 める時間 $T_{A}$ や作用する時間 $T_{B}$ はロープと枠とのギャップに依存すること, 枠がある場合の固有周期は枠が無 い場合の（ $m-0.5 ）$ 倍であることが分かる. なお, 計算式中の級数は荷重波形が概ね図 4 に示寸矩形波に近づく よう $i, k$ とも 512 項まで用いて解析を行った。

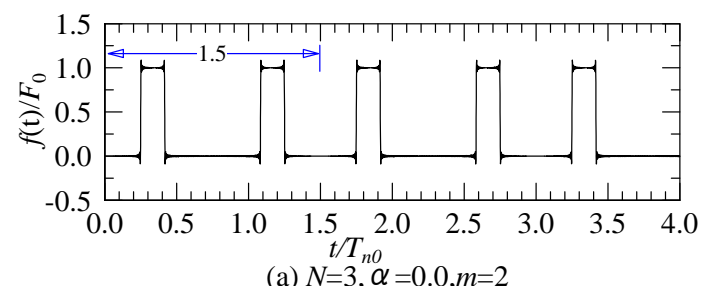

Fig. 7 Time history of reaction force. Reaction force and time are normalized by the initial pulling force and the natural period without vibration suppressor, respectively. 


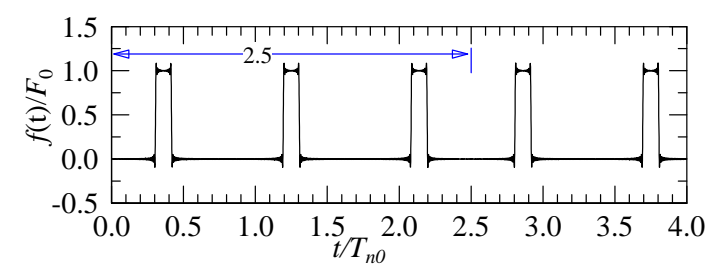

(b) $N=3, \alpha=0.25, m=3$

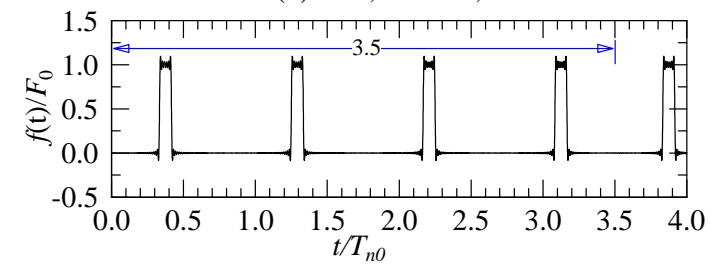

(c) $N=3, \alpha=0.375, m=4$

Fig. 7 Time history of reaction force. Reaction force and time are normalized by the initial pulling force and the natural period without vibration suppressor, respectively. (continued)

\section{$3 \cdot 21$ 点を引張った場合}

\section{$3 \cdot 2 \cdot 1$ ロープ変位分布および変位波形}

自由振動時の変位分布, 時刻歴波形を計算した結果の一例を図 8〜図 13 に示す.引張り位置がロープ全長の $1 / 3$,

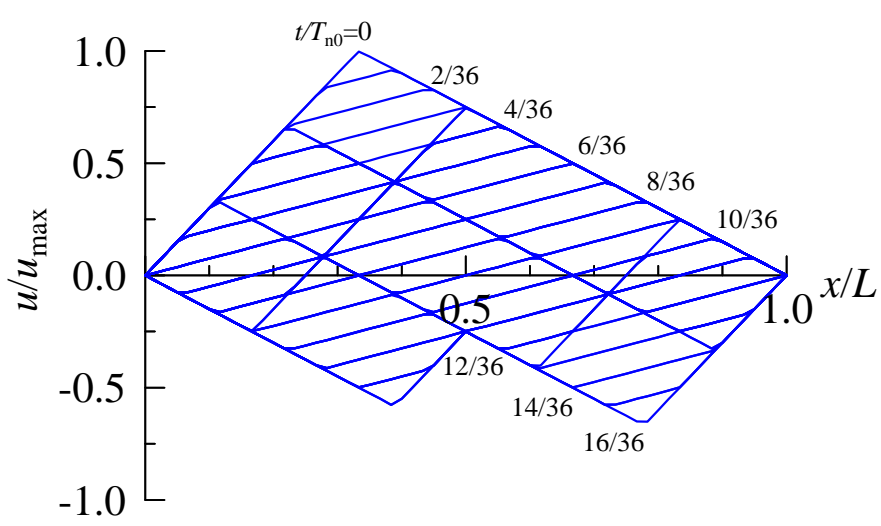

Fig. 8 Vibration mode of rope with vibration suppressor

( $N=3, \alpha=0.25, m=3$ ). Displacement distributions during 1 natural period are plotted. Natural period is $2.5 T_{n 0}$.

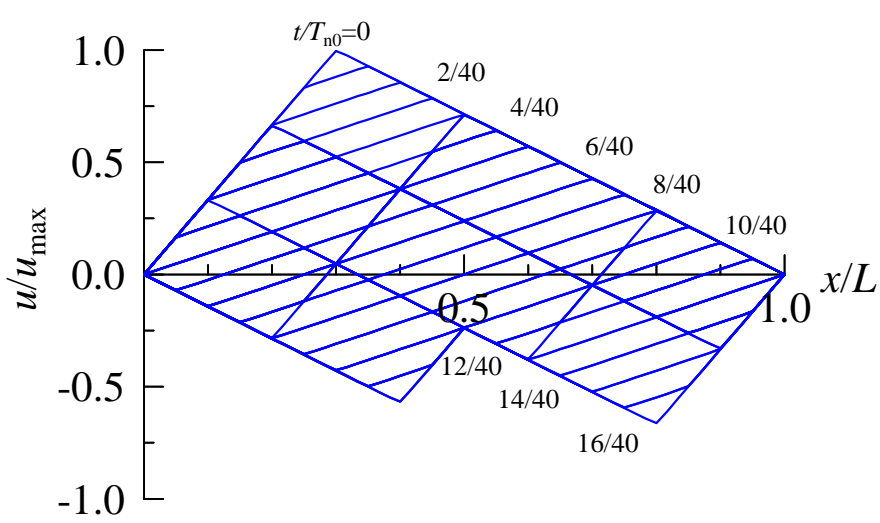

Fig. 10 Vibration mode of rope with vibration suppressor ( $\beta=0.3, \alpha=0.2381, m=3$ ). Displacement distributions during 1 natural period are plotted. Natural period is $2.5 T_{n 0}$.

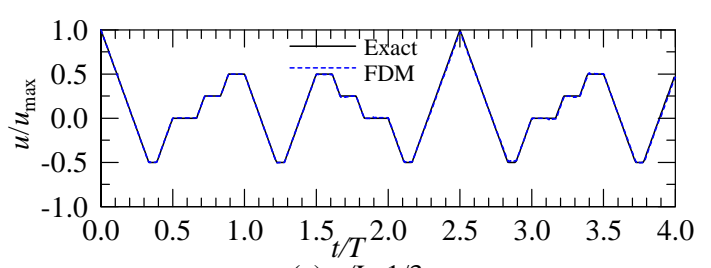

(a) $x / L=1 / 3$

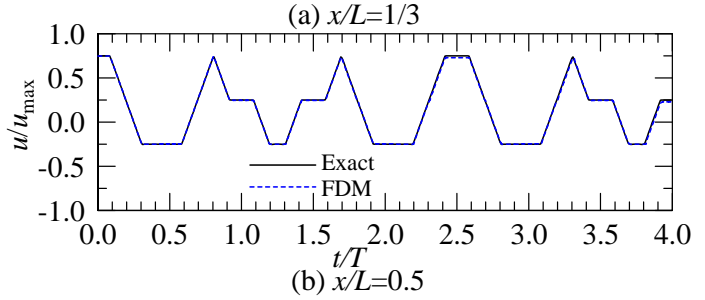

Fig. 9 Time history of rope displacement ( $N=3$,

$\alpha=0.25, m=3$ ). Calculated results by using exact solution and FDM are plotted with the solid (black) lines and dashed (blue) lines, respectively.
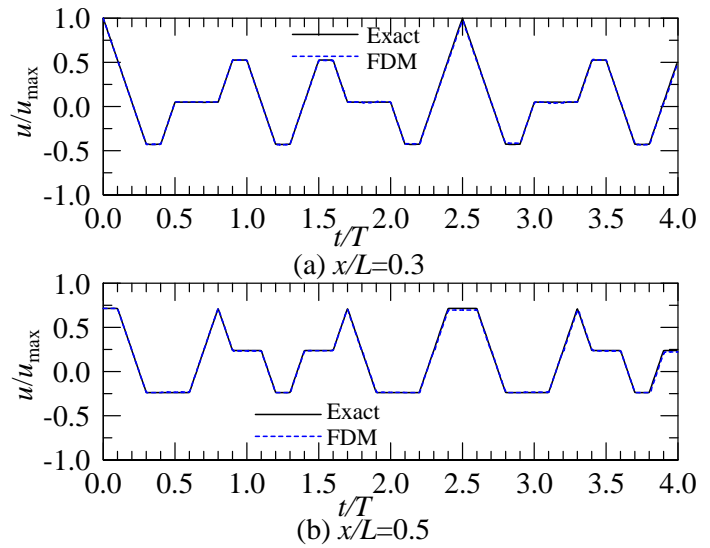

Fig. 11 Time history of rope displacement ( $\beta=0.3$, $\alpha=0.2381, m=3$ ). Calculated results by using exact solution and FDM are plotted with the solid (black) lines and dashed (blue) lines, respectively. 


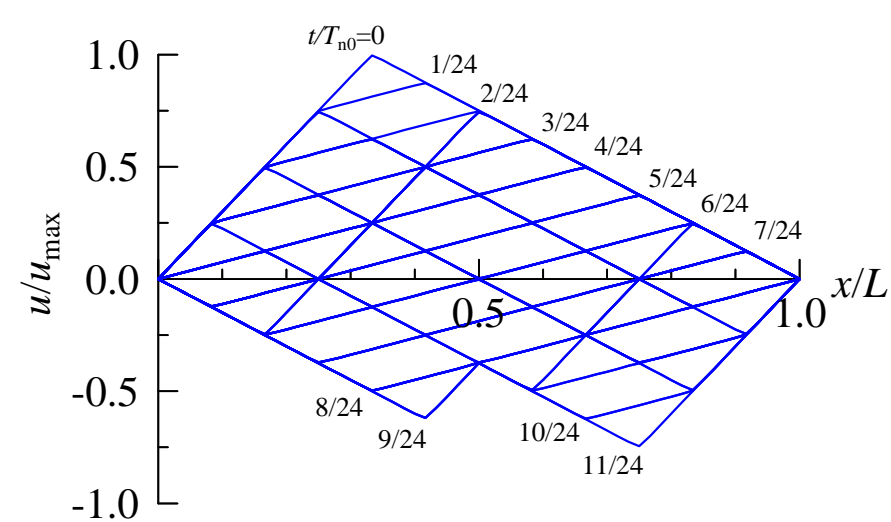

Fig. 12 Vibration mode of rope with vibration suppressor

( $N=3, \alpha=0.375, m=4$ ). Displacement distributions during

1 natural period are plotted. Natural period is $3.5 T_{n 0}$.

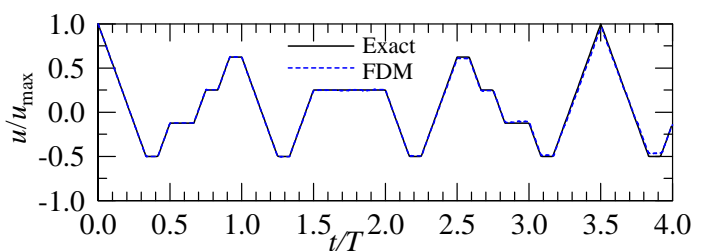

(a) $x / L=1 / 3$

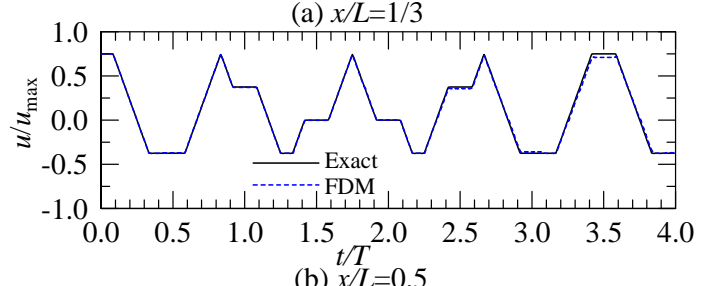

Fig. 13 Time history of rope displacement ( $N=3$, $\alpha=0.375, m=4)$. Calculated results by using exact solution and FDM are plotted with the solid (black) lines and dashed (blue) lines, respectively.

0.3，1/3 で，衝突回数がそれぞれ 3 回，3回，4回の例である. 図 9, 図 11, 図 13 中には差分法による計算結果 も重ね書きしており，両者が良く一致していることが分かる. また，図 8, 図 10, 図 12 から衝突後のロープの傾 きは初期変位の傾きと一致していることが確認できる。なお，計算式（式 (12)，式 (15)，式 (25)，式 (26) 中の級数は $i, k$ とも 512 項まで用いて解析を行った. また, 差分法による数值解析においては, 変位分布における 屈曲点をより正確に表示できるよう分割数 600 で解析を行った．またこれらの図から，固有周期は式(21)に示し たように，枠が無い場合の（ $m-0.5 ）$ 倍（固有振動数はその逆数）であることが分かる.

また, 枠側のロープ最大変位は, ロープ引張り量の $\{0.5+\alpha(1-\beta)\}$ 倍となっていることが, これらの図に示寸数 值解析の結果からも確認できる. この関係は, 初期変位分布の傾きと反対側の変位分布の傾きとが等しいという 幾何学的な関係をもとに誘導することができる.

\section{$3 \cdot 2 \cdot 2$ 周期解を有するための条件}

衝突回数 $m$, ギャップ量を表すパラメータ $\alpha$ および引張り位置を表すパラメータ $\beta$ とが式(17)を満足する場合, 周期解を有することになる. このときの 3 パラメータ間の関係（周期解を有するための条件）を図 14 に示す. 式 (17)およびこの図から，ギャップ量があらかじめ決まっている場合には引張り位置を調整することで，周期解を 有するようにできることが分かる，また引張り位置が決まっている場合には，ギャップ量を調節することで，周 期解を有するようにできることも分かる.

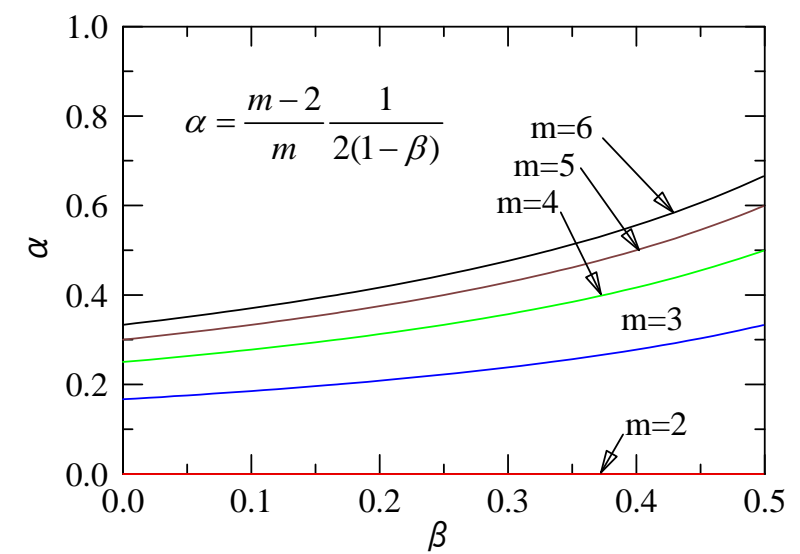

Fig. 14 Relation between parameter $\alpha$ and parameter $\beta$.

This relation is the condition of periodic vibration. 


\section{$3 \cdot 2 \cdot 3$ 衝突回数と固有周期との関係}

衝突回数 $m$ と固有周期との関係を図 15 に示寸. 固有周期は枠がない場合の（ $m-0.5 ）$ 倍となる. また, 衝突 回数 $m$ は整数であるため, 固有周期は飛び飛びの值となる.

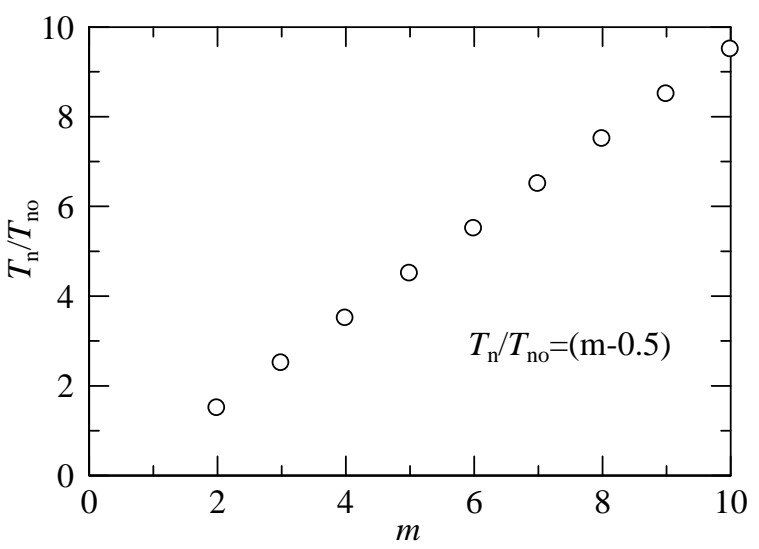

Fig. 15 Relation between collision number $m$ and natural period

$T_{n}$ of vibration. Natural period of vibration is discrete value.

\section{$3 \cdot 3$ 対称に 2 点を引張った場合のロープ変位分布}

2.1 節で説明したとおり, $u(x, t)=u_{1}(x, t)+u_{2}(x, t)$ として計算すれば, 対称に 2 点を引張った場合の自由振動を 計算することができる．この場合の最大変位は $\{N /(2(N-1))\} u_{\max }$ あるいは $u_{\max } /(2(1-\beta))$ となる. 最大変位を $u_{\max }$ とするためには $2(N-1) / N$ あるいは 2(1- $\left.\beta\right)$ を掛ければよい. 図 16 にロープ全長の 1/3 と 2/3 の位置を引 張った場合の変位分布の変化の様子を示寸. この図から, 初期変位分布は式(13)と一致していること, 固有周期

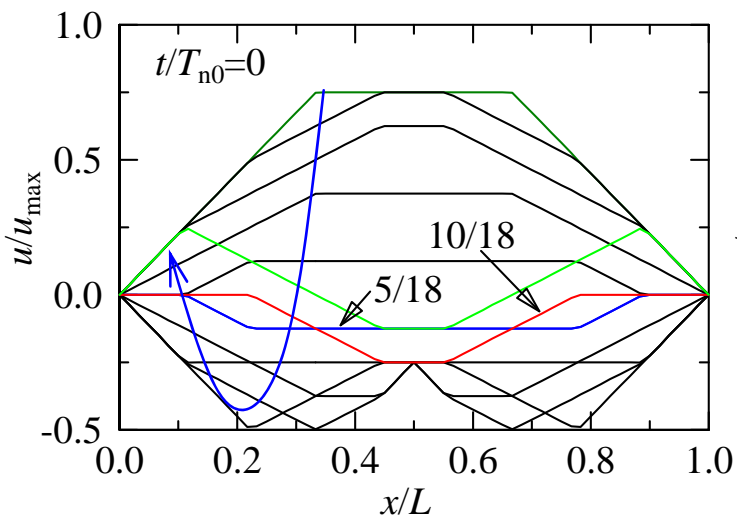

(a) $t / T_{\mathrm{n} 0}=0-11 / 18$

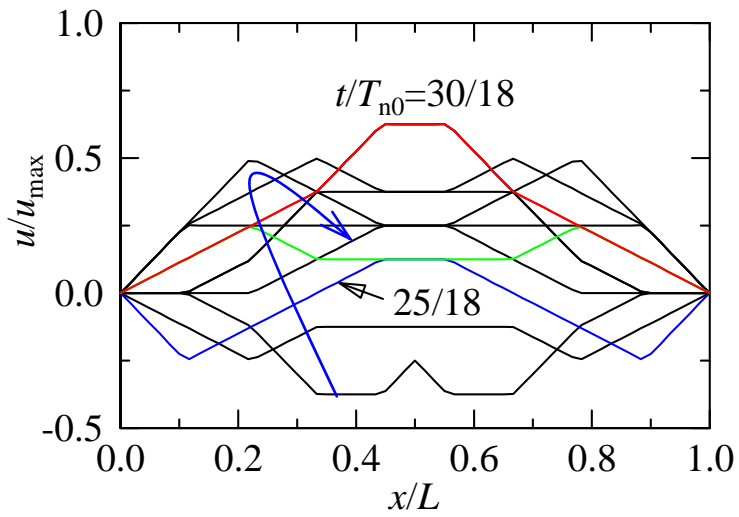

(c) $t / T_{\mathrm{n} 0}=23 / 18-33 / 18$

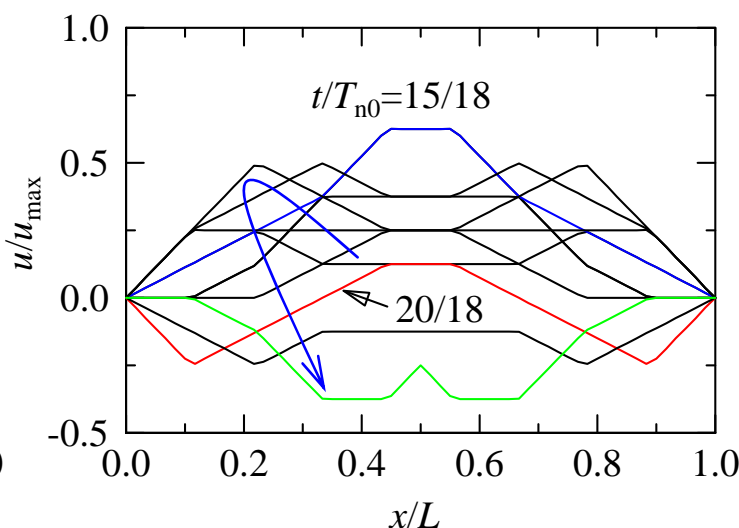

(b) $t / T_{\mathrm{n} 0}=12 / 18-22 / 18$

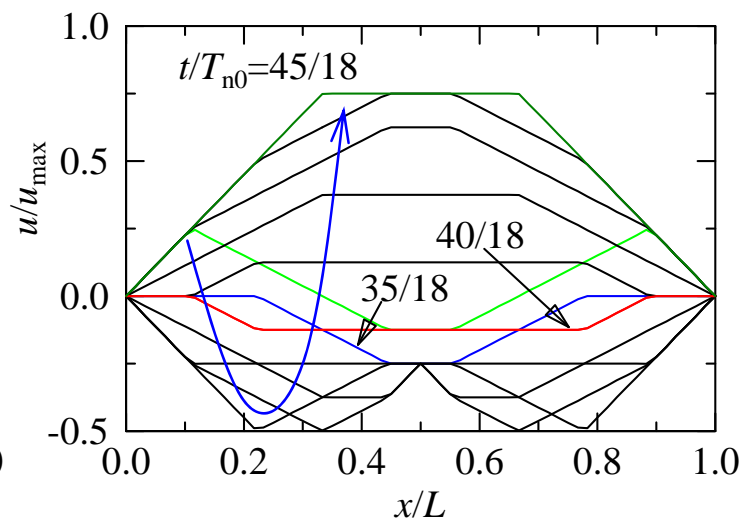

(d) $t / T_{\mathrm{n} 0}=34 / 18-45 / 18$

Fig. 16 Vibration mode of rope with vibration suppressor $\left(u_{1}(x, t)+u_{2}(x, t), N=3, \alpha=0.25, m=3\right)$.

Displacement distributions during 1 natural period are divided into four figures. Natural period is $2.5 T_{n 0}$. 
は 1 点を引張った場合と同様，枠が無い場合の $2.5(=m-0.5)$ 倍であることが分かる.

また，枠側のロープ最大変位は 1 点を引張った場合と同様に引張り量の $\{0.5+\alpha(1-\beta)\}$ 倍であることが分かる. 図 16 では, $\{0.5+\alpha(1-\beta)\} /(2(1-\beta))=0.5)$ となる.これは，対称に 2 点を引張った場合の解は， 1 点を引張った場 合の解を足し合わせたものであるからである.

\section{4. 結 言}

片側中央に 1 個変位拘束部材（振れ止め枠）がギャップ $\delta_{0}$ で配置され，ロープ（弦）全長の $1 / N$ の位置または 任意の位置 $(\beta L)$ を引張った場合の自由振動を対象として, 理論解を求めるとともに数值解析を行い検討した. 得られた結果を要約して以下に示す.

（1）変位拘束部材に作用する荷重をフーリエ級数展開し，各周波数成分に対する応答を重㸚合わせることで，口 一プ中央に 1 個振れ止め枠があり, 衝突回数を $m$ とし, 引張り量 $u_{\max }$ とギャップ $\delta_{0}$ との比を $\alpha$ としたとき に, $\alpha=(1-2 / m) /(2(1-\beta))$ の場合に周期解を有することを示した. またその自由振動についての理論解を得 た.

（2）上記の解を求める過程で, 対称に 2 点を引張った場合（台形状の初期変位）の自由振動についての理論解を 得た。

（3）固有周期は変位拘束部材が無い場合の $(m-0.5)$ 倍（固有振動数は $1 /(m-0.5)$ 倍）であることが判明した.

(4) 変位拘束部材側のロープ最大変位は， ロープ引張り量の $\{0.5+\alpha(1-\beta)\}$ 倍であることを示した.

（5）自由振動についての理論解は，差分法による数值解析結果と良く一致することを確認した。

\section{謝 辞}

本研究の一部は科研費（基盤研究 (C) 15K05859）の助成を受けて行われたものであり，ここに謝意を表す.

\section{文献}

廣瀬伊吹，木村弘之，小川洸，釣合いおもりの上下振動を利用したエレベータ・ロープの横振動抑制，日本機械 学会論文集, Vol. 81, No. 827 (2015), DOI:10.1299/transjsme.trans.15-00102.

勝野友介, 松久寛, 宇津野秀夫, 山田啓介, 澤田勝利, 永久磁石の吸引力を利用したロープの非接触制振一モー ド解析と伝達行列解析の対比一, Dynamics and Deign Conference 2007, No.07-8 (2007), (CD-ROM 論文集，論文 No. 426),pp.1-6.

木村弘之, 中川俊明, 振れ止め枠を有するエレベータ・ロープの横振動解析, 日本機械学会論文集 C 編, Vol. 71, No. 702 (2005), pp. 442-447.

木村弘之, 伊東弘晃, 中川俊明, エレベータ・ロープの横振動解析（第 2 報, 減衰を考慮した場合の強制振動）, 日本機械学会論文集 C 編, Vol. 72, No. 717 (2006), pp. 1440-1445.

木村弘之, 振れ止め枠を有するエレベータ・ロープの自由振動（等間隔に振れ止め枠が配置されている場合），日 本機械学会論文集 C 編, Vol. 79, No. 802 (2013), pp. 1904-1912.

木村弘之，変位拘束部材を有寸る弦の自由振動，日本機械学会論文集，Vol. 80，No. 812 (2014)， DOI:10.1299/transjsme.2014trans0059.

木村弘之, 番匠光平, 動吸振器を用いたエレベータ・ロープの横振動抑制, 日本機械学会論文集, Vol. 81, No. 824 (2015), DOI:10.1299/transjsme.14-00476.

木村弘之, 中央に変位拘束部材を有する弦の自由振動 (弦と変位拘束部材とのギャップが 0 の場合)，日本機械学 会論文集, Vol. 81, No. 824 (2015), DOI:10.1299/transjsme.14-00538.

中川淳一, 新井晋治, コンペンセーションシーブの抑制によるエレベータロープの制振, 日本機械学会 昇降機・ 遊戯施設等の最近の技術と進歩 技術講演会論文集, No. 11-94 (2012), pp. 23-26.

中川俊明，西川孝司，木村弘之，世界最高速エレベーターを支える高信頼性技術，東芝レビュー，Vol． 60，No. 5 (2005), pp. 26-29.

大槻真嗣, 吉田和夫, 永田晃則, 木村弘之, 中川俊明, 超高層ビルのエレベータ・ロープ横振動抑制（時変柔軟 
システムへの非定常最適制御の適用），日本機械学会論文集 C 編, Vol. 68, No.676 (2002), pp. 3589-3596.

渡辺誠治, 西田隆雄, 山根尚志, 長周期地震動におけるエレベーターロープの挙動解析, 日本機械学会 昇降機・

遊戯施設等の最近の技術と進歩＼cjkstart技術講演会論文集，No. 06-67 (2007), pp. 15-18.

安田仁彦，振動工学（基礎編） (2000), pp.143-144，コロナ社.

\section{References}

Hirose, I., Kimura, H. and Ogawa, K., Suppression of transverse vibration of elevator rope using vertical vibration of counterweight, Transactions of the JSME (in Japanese), Vol. 81, No. 827 (2015), DOI:10.1299/transjsme.15-00102.

Katsuno, Y., Matsuhisa, H., Utsuno, H., Yamada, K. and Sawada, K., Non-contact vibration control of elevator rope using magnetic force -Comparison between modal analysis and transfer matrix analysis-, Proceeding of the Dynamics and Design Conference 2007, No. 07-8(2007),CD-ROM (Paper No. 426) ,pp.1-6 (in Japanese).

Kimura, H. and Nakagawa, T., Vibration analysis of elevator rope with vibration suppressor, Transactions of the Japan Society of Mechanical Engineers, Series C, Vol. 71, No. 702 (2005), pp. 442-447 (in Japanese).

Kimura, H., Ito, H. and Nakagawa, T., Vibration analysis of elevator rope (2nd report, Forced vibration of rope with damping), Transactions of the Japan Society of Mechanical Engineers, Series C, Vol. 72, No. 717 (2006), pp. 1440-1445 (in Japanese).

Kimura, H., Free vibration of elevator rope with vibration suppressors (When vibration suppressors are arranged at equal intervals), Transactions of the Japan Society of Mechanical Engineers, Series C, Vol. 79, No. 802 (2013), pp. 1904-1912 (in Japanese).

Kimura, H., Free vibration analysis of a string with vibration suppressor, Transactions of the JSME (in Japanese), Vol. 80, No. 812 (2014), DOI:10.1299/transjsme.2014trans0059.

Kimura, H. and Bansho, K., Suppression of transverse vibration of elevator rope using dynamic damper, Transactions of the JSME (in Japanese), Vol. 81, No. 824 (2015), DOI:10.1299/transjsme.14-00476.

Kimura, H., Free vibration analysis of a string with vibration suppressor located at center of the string (When gap between string and vibration suppressor is zero), Transactions of the JSME (in Japanese), Vol. 81, No. 824 (2015), DOI:10.1299/transjsme.14-00538.

Nakagawa, J. and Arai., S., Damping of elevator rope swing by resting movement of compensation sheave, Elevator, Escalator and Amusement Rides Conference, No. 11-94 (2012), pp. 23-26 (in Japanese).

Nakagawa, T., Nishikawa, T. and Kimura, H., High-reliability technologies for world's fastest elevators, Toshiba Review, Vol. 60, No. 5 (2005), pp. 26-29 (in Japanese).

Otsuki, M., Yoshida, K., Nagata, K., Kimura, H. and Nakagawa, T., Vibration control for rope-sway of elevator of high-rise building (Application of nonstationary optimal control to time-varying flexible system), Transactions of the Japan Society of Mechanical Engineers, Series C, Vol. 68, No. 676 (2002), pp. 3589-3596 (in Japanese).

Watanabe, S., Nishida, T. and Yamane, T., Elevator rope dynamics during long-period ground motion, Elevator, Escalator and Amusement Rides Conference, No. 06-67 (2007), pp. 15-18 (in Japanese).

Yasuda, K., Vibration Engineering (Fundamentals) (2000), pp. 143-144, Corona Publishing Co., LTD (in Japanese). 